\title{
Article \\ The Buddhist Philanthropist: The Life and Times of Lee Choon Seng
}

\author{
Guan Thye Hue ${ }^{1,2,3,4, *}$, Chang Tang ${ }^{1}$ and Juhn Khai Klan Choo ${ }^{2}$ \\ 1 Centre for Research on Southeast Asian Chinese Documents, Xiamen University Malaysia, \\ Sepang 43900, Selangor, Malaysia; chs1909086@xmu.edu.my \\ 2 Department of Chinese Studies, Xiamen University Malaysia, Sepang 43900, Selangor, Malaysia; \\ mch2004001@xmu.edu.my \\ 3 Asia Research Institute \& Department of Chinese Studies, National University of Singapore, \\ Kent Ridge 119077, Singapore \\ 4 Fo Guang Shan Institute of Humanistic Buddhism, Kaohsiung 2404-2408, Taiwan \\ * Correspondence: chshueg@nus.edu.sg
}

Citation: Hue, Guan Thye, Chang

Tang, and Juhn Khai Klan Choo. 2022.

The Buddhist Philanthropist: The

Life and Times of Lee Choon Seng.

Religions 13: 147. https://doi.org/

10.3390/rel13020147

Academic Editor: Jack Meng-Tat Chia

Received: 19 December 2021

Accepted: 28 January 2022

Published: 7 February 2022

Publisher's Note: MDPI stays neutral with regard to jurisdictional claims in published maps and institutional affiliations.

Copyright: (C) 2022 by the authors. Licensee MDPI, Basel, Switzerland. This article is an open access article distributed under the terms and conditions of the Creative Commons Attribution (CC BY) license (https:// creativecommons.org/licenses/by/ $4.0 /$ )

\begin{abstract}
This article examines the life and times of Lee Choon Seng (李俊承), exploring his role as a prominent lay Buddhist leader in Singapore and the broader Chinese Buddhist world. Lee Choon Seng's influence in society, as well as his adherence to Chinese Mahayana Buddhism, laid an important foundation for him to carry out philanthropic activities within the Buddhist community in Singapore. Before World War II, Lee Choon Seng acted as a patron of the Dharma, sponsoring Buddhist activities and advocating for the idea of revitalizing China in the spirit of Buddhism. During the Japanese Occupation, Lee Choon Seng initiated and led the Buddhist philanthropy movement, which converged into a huge developmental trend in society. In the postwar period, Lee Choon Seng established and served as the inaugural chairman of the Singapore Buddhist Federation, making him a key figure in unifying the Buddhist community in Singapore. As this article demonstrates, Lee Choon Seng's socio-religious model, which was comprised of a combination of Mahayana Buddhism with social charity and welfare, was an important factor for the promotion of Buddhism among the Chinese community in Singapore.
\end{abstract}

Keywords: Lee Choon Seng; lay Buddhist; Chinese Buddhism; Buddhist philanthropy; Singapore Buddhist Federation

\section{Introduction}

Lee Choon Seng, a well-known Chinese businessman with relatively high Buddhist attainments in Singapore, made outstanding contributions to the spread of Buddhism in Singapore and the development of local social philanthropy. During the ups and downs of the era, Choon Seng experienced the fall of the Qing dynasty, the rise of the Republic of China, the British colonization in Southeast Asia, the Japanese Occupation, and the independence of Singapore. It was not an easy feat for him to maintain the delicate balance of his political participation, corporate management, and spiritual cultivation. In addition, his Buddhist ideology was also constantly developing amid political changes. For example, as a Buddhist layman, he changed his role from a lay Buddhist patron to the leader of the Singapore Buddhist Federation in the post-colonial period. He was also involved in advocating for the spirit of Buddhism to save China by localizing Buddhism after the war. The reasons behind the changes should not be ignored because they form the essential means for understanding the history and development of Buddhism in Singapore.

However, little research has been carried out on Lee Choon Seng to date. Previous studies on Lee Choon Seng are brief (Kua 2012, pp. 115-16). They have either analyzed his literary works (Ho 2013, pp. 28-34) or focused on his business and social activities (Chai 2014). Although an article has briefly examined Lee Choon Seng's role in the establishment 
of the Singapore Buddhist Federation (Chia 2016), it tells us little about his activities in the broader Buddhist community. Therefore, more attention is needed to examine Lee's contributions to the Buddhist community in Singapore and the broader Buddhist world. In general, the current research on Lee Choon Seng's contributions to Buddhism is still in its infancy and lacks a systematic arrangement analysis.

This article examines the life and times of Lee Choon Seng, exploring his role as a prominent lay Buddhist leader in Singapore and in the broader Chinese Buddhist world. It hopes to fill a gap in the current research, presenting Lee Choon Seng's contributions to the development of Buddhism in Singapore. By doing so, this study seeks to shed some light on the life of one of the most important lay Buddhists in Singapore's history. This study, divided into three parts, seeks to present the activities of Lee Choon Seng during three periods of his life: the pre-World War II era, the Japanese Occupation period, and the post-colonial era. These three periods represent different stages in the development of Lee Choon Seng's life. In his different life experiences, he also played different roles in the promotion of the Buddhist movement. Before World War II, Lee Choon Seng was a successful businessman and, using his strong financial power to provide financial aid for Buddhist activities, he became one of the lay Buddhist patrons. However, during Japanese rule, he served with the Japanese and was misunderstood as a pro-Japanese activist. This could be said to be the most painful period for him, but the war conditions actually contributed to his strong promotion of Chinese Buddhist charities. After World War II, Lee Choon Seng became the chairman of the Singapore Buddhist Federation, unifying Singaporean Buddhism towards localization and bringing local Buddhism to a mature stage of development. These three stages are all important turning points in Lee's life, and therefore his influence on Singaporean Buddhism at different times can be better understood in the context of the corresponding era.

\section{Lee Choon Seng's Social and Religious Networks before World War II}

Lee Choon Seng (1888-1966) was born in Yongchun County, Fujian Province, China. Choon Seng's father, Lee Lip Chai (李立斋), was a Chinese immigrant entrepreneur in Seremban, Malaya. When Lee Choon Seng was 17 years old, he was called upon by his father to study business in Nanyang, and later expanded his career to Singapore (Lee 1956, p. 61). ${ }^{1}$ When Choon Seng settled down in Singapore, he quickly extended his business network and became an important leader in the local Hokkien community. Before World War II, Choon Seng served as the chairman of the Singapore Chinese Chamber of Commerce and the acting chairman of the Singapore China Relief Fund. Like his contemporaries who were Singapore Chinese leaders such as Tan Kah Kee (陈嘉庚), Lee Kong Chian (李光前), and Aw Boon Haw (胡文虎), Lee Choon Seng was loyal and patriotic to his motherland and actively involved in supporting China's Anti-Japanese War. However, the difference was that Choon Seng played the role of "guardian" (护法) in the Buddhist world (Hue 2013, p. 18). He not only had high Buddhist attainments but also enthusiastically promoted Buddhist activities to achieve the ideal of saving the country through Buddhism.

In the early 19th century, there were many devout and faithful Buddhists among the early Chinese immigrants who came to Nanyang. They gained spiritual sustenance from the religion (Sheng 2019, p. 46). Moreover, some Singapore Chinese leaders, such as Tan Kah Kee and Aw Boon Haw, met and discussed Buddhism with Master Taixu (太 虚) during his visits to Singapore (Chia 2020b, pp. 37-38; Tan 2009, p. 32). ${ }^{2}$ These indicate that the Chinese immigrant society in Singapore at that time was familiar with Chinese Buddhism. Lee Choon Seng's earliest contact with Buddhism was related to his family. In the early stage of his life, Lee Choon Seng's father, Lee Lip Chai, donated to and rebuilt the Dongguan Bridge and the Guanyin Buddhist niche inside the bridge (completed in 1914) in his hometown (Shi 2021a). Unexpectedly, a wind disaster destroyed the bridge within a short time (Shi 2021a). Ng Tze Hui (黄慈晖), the mother of Lee Choon Seng, dreamt that Guanyin (观音) would commission her to repair the bridge. Thereafter, Choon Seng's mother instructed him to repair the bridge and the Guanyin Buddhist niche (completed 
in 1923) with a sole proprietorship (Shi 2021a). The deeds of Lee Lip Chai and his son in repairing the bridge and the niche one after another suddenly became an anecdote in their hometown and show the connection of Lee Choon Seng to Buddhism in his early years.

It was not until 1925 that Lee Choon Seng formally took the initiative to develop a relationship with Buddhism. When he went to Putuo Mountain in Zhoushan, China to perform rituals, he had a great admiration for Master Yinguang (印光), a Chinese Buddhist pure land master, and requested to become his lay disciple. Master Yinguang gave Lee Choon Seng the dharma title "Hui Jue" (慧觉). Thereafter, he called himself "Hui Jue Layman" (慧觉居士) (Shi 2021b). Master Yinguang's works recorded Lee Choon Seng's donation of 5000 dollars twice to his teacher, revealing a deep relationship between the master and apprentice and Lee Choon Seng's pious devotion to Buddhism (Shi 2021b). ${ }^{3}$ It explains why he was willing to take out huge sums of money to support the master. Master Yinguang was a famous Chinese Buddhist reformer at that time. In the early part of the 20th century, he launched the pure land revival movement ${ }^{4}$ based on a lay-oriented and secular form, thus transforming the movement into a huge secularization movement in Chinese Buddhism (Wei 2007, pp. 52-53; Ritzinger 2017, p. 53; Jan 2016, pp. 39-43). Master Yinguang played an important role in leading Buddhist laymen to participate in Buddhist activities. The first layman's Buddhist grove in China was founded in Shanghai, ${ }^{5}$ and he was the guiding teacher (Ritzinger 2017, p. 59; Jia and Zhe 2018, pp. 16-17). Lee Choon Seng actively participated in Buddhist activities later and was most likely influenced by Master Yinguang. An example is his naming of the villa in Singapore, which originally was the garden compound known as the Shanghai Lay Buddhist Grove, as the Enlightenment Garden (觉园) (Jan 2016, pp. 39-40; Lee 1950, p. 3).

However, it was the South China Sea Buddhist networks formed from the Nanputuo Monastery in Xiamen that had a major impact on Lee Choon Seng's Buddhist ideas and the development of Buddhism in Singapore. From the end of the Qing Dynasty to the early years of the Republic of China, Chinese Buddhism was undergoing a modernization process, and the Nanputuo Monastery in Xiamen, which was under the leadership of modernist monks, became the center of the modernist Buddhist movement in South China (Chia 2020a, p. 9). In the 1920s, the famous Master Taixu became the abbot of the Nanputuo Monastery, and actively promoted the modern Buddhist movement overseas, especially in Southeast Asia, and especially the dissemination of modern Chinese Buddhist thought to the Chinese community in Singapore (Chia 2020a, pp. 7-12). The eminent monk who cultivated and spread modern Chinese Buddhism in Singapore was not Master Taixu, but Venerable Zhuandao (转道), a monk who also came from the Nanputuo Monastery. He came to Singapore around 1913, but he was not in a hurry to promote Buddhist thought. Instead, he appeared in the market, donated medicine, and held welfare activities among the people (Hue 2013, p. 116). Thereafter, with the support of local Buddhist laymen, Venerable Zhuandao's Buddhist activities successively established Buddhist temples and organizations such as the Kong Meng San Phor Kark See Monastery, the Chinese Buddhist Association, and the English Buddhist Association. He also invited famous Chinese monks, such as Taixu and Yuanying (圆瑛), to come and lecture, setting off a climax for the spread of Chinese Buddhism in Singapore (Hue 2013, p. 117).

The Buddhist philanthropy shown by Venerable Zhuandao influenced Lee Choon Seng. In 1933, Lee Choon Seng eagerly responded to the Buddhist activities initiated by Venerable Zhuandao and, together with Khoo Seok Wan (邱菽园), Zhuang Du Ming (庄笃明), and other Buddhist laymen, formed the "Singapore Buddhist Scripture Circulation Center" for printing and distributing Buddhist scriptures to the public. Later, the organization developed into the "Singapore Buddhist Lodge" in 1934 (The Singapore Buddhist Lodge 2021). The Buddhist Lodge was led by Lee Choon Seng, and Venerable Zhuandao served as a Buddhist lecturer. Every Wednesday and Sunday night, Venerable Zhuandao taught the practice of Buddhist chanting and meditation, so that Buddhist laymen could have more opportunities to acquaint themselves with Buddhism through this organization (Hue 2013, p. 117). The establishment of the Singapore Buddhist Lodge can be regarded as the 
beginning of layman Buddhism in Singapore (Hue 2013, p. 125). It also reflected that the modern Chinese Buddhism carried out by Venerable Zhuandao and his team broke the old Buddhist order of being segregated from the secular world and brought about the gradual recognition of the Buddhist laymen in the Buddhist world (Chia 2020b, pp. 12-45; Zhang 2014, pp. 24-26).

The Chinese Buddhism preached in Singapore by the monks of the Buddhist Network of the Nanputuo Monastery in Xiamen at that time was the implementation of the philosophy of Humanistic Buddhism (人间佛教) advocated for by Master Taixu. Master Taixu reformed traditional Buddhism with the concept of rensheng fojiao (Buddhism of life) and emphasized that Buddhists should get rid of the superstitions about the religion, be concerned about the individual believer and his daily life attitudes, and engage with services to guide the masses and bring them benefits (Long 2000, p. 59; Bingenheimer 2007, p. 146). In short, his thought aimed to improve the human world through ethical actions and propagate a humanistic form of Buddhism that he called "Engaged Buddhism" and involves social welfare activities that benefit society (Kimball 2000, p. 11; Bingenheimer 2007, p. 146). Thus, these Buddhist monks put philanthropy, in Chinese terms called "cishan" (慈善), the doing of kind and compassionate acts to each other, at the center of Buddhist practice, and this naturally needed the support of lay Buddhists to carry out these activities (Ritzinger 2017, p. 61; Laliberté et al. 2011, pp. 142-43). What Master Taixu advocated for was actually more of a Buddhist revival movement. The Mahayana Buddhist spirit inherited from China in the Sui and Tang Dynasties was originally focused on Buddhist philanthropy, which engaged in many welfare activities, but, later, with the decline of Chinese Buddhism, these activities of Buddhist monasteries and monks gradually became detached from the public (Long 2000, pp. 55-56). In the turbulent times of early modern China, especially in the 1930s, the Anti-Japanese war period, it was necessary to reawaken the philanthropic spirit of Chinese Mahayana Buddhism to promote peace and national salvation.

In Singapore, Venerable Zhuandao, Daojie (道阶), Cihang (慈航), and other masters from Fujian cooperated with Buddhist laymen to advocate for the promotion of Buddhist education and the charitable spirit of Chinese Mahayana Buddhism to secular society (Hue 2013, pp. 118-24). It can be seen from Lee Choon Seng's participation in the establishment of the Singapore Buddhist Lodge that he was also deeply influenced by the thoughts of these Buddhist monks. In the 1930s, Lee Choon Seng successfully built up prestige in the Singapore Chinese Community and began to be a dominant Chinese banker (Nanyang Siang Pau 1933; Malaya Tribune 1933; Morning Tribune 1936; Malaya Tribune 1938). ${ }^{6}$ From 1931 to 1933, he served as the chairman of the Singapore Chinese Chamber of Commerce (Malaya Tribune 1931; Singapore Chinese Chamber of Commerce \& Industry 1982, p. 240), the most important Chinese association in Singapore. Therefore, the financial resources he accumulated in the business field provided him with sufficient capital to promote Buddhist activities in Singapore. After the outbreak of the Anti-Japanese War in China, Lee Choon Seng and the other three who had important positions in the field of religion and culture, Ye Jiyun (叶季允), Shi Ruiyu (释瑞于), and Khoo Seok Wan, all paid attention to the development of the current situation in Singapore and China, and even advocated for the idea of saving the country through Buddhism. They were the so-called four talented men of Singapore (星洲四才子) at that time. Lee Choon Seng used the Singapore Buddhist Lodge as a place to promote Buddhism to the public. The organization often attracted social celebrities and literati for social gatherings, which became a foothold for local Chinese Buddhism to be integrated into society (Hue 2013, p. 125).

The so-called Buddhist idea of saving the country also originated from modern Buddhist thought from southern China. In the early days, Master Taixu emphasized that Buddhists should pay attention to current affairs and political developments, while another Xiamen monk, Yuanying, founded the China Buddhist Association Disaster Relief Group (中国佛教会灾区救护团) and raised money for the relief fund in Southeast Asia when the Anti-Japanese War broke out in 1937 (Chia 2020a, p. 13). For modern Chinese Buddhism at 
that time, the revival of Chinese Buddhism was equivalent to the revival of the Chinese nation, so the promotion of the cause of Chinese Buddhism was inseparable from the revitalization of the nation. This was because the Buddhist reformists in China, such as Master Taixu, believed that Buddhism was a part of the Chinese cultural tradition, and it infused nationalism into the project of Buddhist reform (Ritzinger 2017, p. 56). Therefore, as Jessica and Lai (2013, p. 21) state, in the thought of modern Chinese Buddhism, "Chinese Buddhists not only viewed religion as an indispensable component in the formation of the nation, but also asserted a national identity deeply rooted in Buddhism." Therefore, looking back at the situation in Singapore, it is not difficult to understand the spirit of saving the country through Buddhist education advocated for by the four talented men of Singapore and Master Cihang, because they hoped to use modern Chinese Buddhism, which emphasized the key teachings of Mahayana Buddhism, to help and save the nation (China).

In the 1930s, the Hokkien leaders in the Singapore Chinese community, such as Lee Choon Seng, Tan Kah Kee, Lee Kong Chian, and Tan Ean Kiam (陈延谦), initiated the national salvation movement immediately to support China in the Anti-Japanese War. Starting in 1937, Lee Choon Seng served as the vice-chairman of the Singapore China Relief Fund, and, in 1940, he served as the acting chairman of the organization on behalf of Tan Kah Kee (Nanyang Siang Pau 1940; The Straits Times 1940). ${ }^{7}$ Furthermore, he also purchased 100,000 dollars' worth of patriotic public bonds issued by the Chinese government in 1937 and dedicated the bonds to China Academia Sinica as a fund to support the motherland's science and technology research and development (Nanyang Siang Pau 1937; Nanyang Siang Pau 1939). At the same time, Lee Choon Seng still did not forget to promote the spirit of Buddhism because the Buddhist thoughts originating from southern China as shown above and adhered to by Lee Choon Seng and other Buddhist monks and laymen in Singapore were closely connected to the idea of his patriotism to and the national salvation of his motherland. Hence, this brought his religious thoughts even closer to his sense of "Chineseness".

In 1938, Lee Choon Seng led Buddhist monks and laymen of Singapore to donate to and build a Chinese temple costing 30,000 dollars in Sarnath, India (Lee 1940, p. 1). The donation that was made by Lee Choon Seng in India was part of the action to "save and support China" because the most significant purpose of establishing the Chinese Temple in Sarnath was to deliver the Buddhist spirit of peace (Lee 1940, p. 1). The undertaking also corresponded with his support of China at this time and to show his desire for an early end to the war. In the foundation-laying ceremony of the Chinese Temple in Sarnath, Lee Choon Seng delivered a speech that emphasized that the disadvantages of today's world lay in the excessive emphasis on material pursuits and the ignorance of the spirit. He said that, if the spiritual level of the individual could be improved with the teachings of Buddhism, people would cultivate a peaceful attitude and achieve a balance between material and spiritual pursuits (Lee 1940, p. 2). ${ }^{8}$ This was Choon Seng's interpretation of the function of Buddhism to transform society, and it reflected his emphasis on the practical significance of Buddhism to help and save the community. Next, Lee Choon Seng mentioned that connecting China's, India's, and other Asian countries' feelings with one another was one of the purposes of establishing the temple (Lee 1940, pp. 2-7). In other words, Chinese Buddhism was not only a religion that belonged to Lee Choon Seng and other Buddhists but also represented their Chinese identity and Buddhism with Chinese characteristics. Therefore, the promotion of the connection of Chinese Buddhism to other nations was not considered a pure religious activity but it was also related to the rise and fall of the country (China). Choon Seng's speeches showed that his admiration for Buddhism stemmed from his belief that Buddhist activities might benefit society and the nation. To put it simply, it comes from the concept of Humanistic Buddhism that was encouraged by Master Taixu, or more precisely, the ideological product of the spread of modern Chinese Buddhism from Xiamen to Singapore (as shown above). 
The Buddhist thought of Lee Choon Seng could also be seen in his writings. In his book, Lee Choon Seng emphasized three ways to revitalize Chinese Buddhism: firstly, Buddhists and temples should not be isolated from society, as Buddhism must be connected with the community to help the poor and sick; secondly, Buddhist temples must be engaged in production, so that monks can be self-sufficient and utilize the surplus money to engage in social services; and thirdly, to increase the wisdom among Buddhists (Lee 1940, pp. 105-8). Lee Choon Seng aggressively expanded his business, opened banks, and served on the committee in various associations; on the other hand, he solely funded the reconstruction of the Dongguan Bridge, initiated a fundraising society to support China's Anti-Japanese War, and donated land to build a Chinese temple in Sarnath to strengthen the ties between China and India. Choon Seng demonstrated that while he was expanding his business and social activities, he was also contributing back to society.

Although the Buddhist activities that Lee Choon Seng had participated in and promoted before World War II were not as crucial as the Buddhist activities in the later part of his life, his dedication to Chinese society coincided with the spirit of Mahayana Buddhism that he had advocated for and was society-oriented and beneficial for the world. In short, Lee Choon Seng invested a great deal of money and effort into the spread of Buddhism in Singapore before World War II, which laid the foundation for him to become Singapore's Buddhist leader from the Japanese Occupation to the postwar period.

\section{Lee Choon Seng's Contributions to Buddhism during the Japanese Occupation}

As a prominent member of society who supported Buddhism before World War II, Lee Choon Seng became a "pioneer" who promoted the spread of Buddhism in Singapore during the Japanese Occupation. When Singapore was under the dictatorship of the Japanese government, there was no suppression of Buddhism in this period, since Japan had adopted Buddhism as its state religion (Hue 2013, p. 128). ${ }^{9}$ Under these circumstances, Lee Choon Seng used his social status as a leader of the Chinese community and his social network during this period to promote and participate in Buddhist charity activities, which enabled Buddhist philanthropists to benefit more people. This made Buddhism a spiritual refuge for people in a war-torn environment. By way of Lee Choon Seng's contribution to Buddhist activities during the Japanese Occupation, Buddhism developed rapidly, which greatly increased the number of Buddhist devotees in Singapore at that time (Abeyratne 1956, p. 29). ${ }^{10}$

During the Japanese Occupation, Lee Choon Seng was forced to stay in Singapore (Lee 1950, p. 103). ${ }^{11}$ He was arrested by the Japanese Kempeitai on the charge of "representing Mr. Tan Kah Kee as the chairman of the Singapore China Relief Fund in 1940" and almost faced the death penalty, but he was eventually released without charge on the seventh day of his arrest (Lee 1950, p. 103). Later, Lee Choon Seng was forced to serve on the committee of the Syonan Overseas Chinese Association established by the Japanese government (Chua and Hsu 1984, pp. 376-416). ${ }^{12}$ However, at the same time, Lee Choon Seng decided to temporarily move the Singapore Buddhist Lodge to the Thian Hock Keng Temple, and he cooperated with Zhuang Duming, a Buddhist layman, to provide free medical treatment and food to the poor and the sick (Lee 1950, p. 103; Hue 2013, p. 126). Moreover, the association provided a pension of 10 dollars per month to poor persons who were over 70 years old (Lee 1950, p. 103). Additionally, the Overseas Chinese Association also set up an overseas Chinese refugee shelter in Shuang Lin Monastery, which was also managed and hosted by Lee Choon Seng, to promote the spirit of Buddhism and to rescue and accommodate nearly 500 Chinese refugees (The Syonan Shimbun 1943a; Lee 1950, p. 103; Chua and Hsu 1984, p. 432).

In 1943, the Allied forces began to counterattack Singapore and Malaya, which caused heavy casualties and injuries to people. Thus, Lee Choon Seng called upon his fellow Buddhists, including the monks and laymen, to establish the Chinese Buddhist Relief Association, and Choon Seng served as the chairman (The Syonan Shimbun 1945a; Lee 1950, p. 104). This association obtained financial and spiritual support from the Chinese Buddhist 
temples across the country, and dozens of Singapore's Buddhist temples were turned into temporary relief centers; eight branches altogether were involved (The Syonan Shimbun 1945a). As a Chinese Buddhist leader, Choon Seng mobilized Buddhists throughout the entire country to conduct rescue work for the refugees affected by the war (The Syonan Shimbun 1945a). Additionally, the Japanese government adopted a loose management policy on Buddhist charity activities (The Syonan Shimbun 1945a, 1945b), ${ }^{13}$ which made this association into one of the largest relief organizations helping people in Singapore at that time (Hue 2013, pp. 126-28). ${ }^{14}$ Lee Choon Seng and other Buddhists implemented the spirit of caring in Buddhism to provide relief to all people regardless of class and race. This may have helped the religion to break ethnic boundaries and make some of the people convert to and embrace Buddhism. (The Syonan Shimbun 1945a). The Chinese Buddhism that was promoted by Lee Choon Seng and the Buddhists spread to every corner of the community through relief activities.

Later, Lee Choon Seng led the Chinese Buddhist Relief Association to cultivate more than two hundred acres of farms on Batam Island, Indonesia in order to build the "Gion Village" (祇园) as a temporary refuge for Buddhists at a cost of more than two million dollars (The Syonan Shimbun 1945b; Lee 1950, p. 104; Chua and Hsu 1984, p. 454). Lee Choon Seng wrote a poem entitled "Written for Banchan Temple when Boat Riding on Batam Island” (淡岛舟次呈半禅寺叠韵), which expressed his hope that people who came to this place would be able to alleviate their sufferings and stay peacefully in this Buddhist paradise (Lee 1950, p. 27). From supporting the refugees in Singapore with the Thian Hock Keng Temple and the Shuanglin Monastery, and cultivating farms on Batam Island, it can be seen that Lee Choon Seng, as a Buddhist layman, chose Buddhist temples as places to promote charity activities. As a result, lower-class people who received donations from Buddhist temples would undoubtedly be grateful for Buddhism in their hearts.

At this level, it is easier to understand the influence of Lee Choon Seng on the development of Buddhism in Singapore in this period. The Buddhist charity activities led and conducted by Lee Choon Seng, as mentioned above, were equivalent to telling the people that these Buddhist temples and their associations had been mobilized to help people. The encouragement of the local Chinese community and the Japanese government for relief activities in Buddhist temples naturally attracted numerous people to learn about and participate in Buddhist activities voluntarily. Factors such as Lee Choon Seng's active promotion of Buddhist activities and the Japanese government's tolerant policy toward the religion led the number of Buddhist believers in Singapore to increase to more than 100,000 people during the Japanese Occupation and enhanced the rapid development of Buddhism in Singapore (Abeyratne 1956, p. 29). Venerable Beng Tee greatly appreciated Lee Choon Seng's contribution to the development of Singaporean Buddhism during the period of Japanese Occupation (Abeyratne 1956, p. 29).

The prosperous development of Buddhism in Singapore during the Japanese Occupation was due to multiple factors, but it should not be overlooked that Lee Choon Seng played an extremely important role in the process. It can be seen from the above that Lee Choon Seng played an important role in the transformation of the Thian Hock Keng and Shuanglin Temples into relief centers, the establishment of the Chinese Buddhist Relief Association to help refugees, and the development of the Batam Buddhist sanctuary. The influence of the social network of Lee Choon Seng made him win support from Chinese Buddhists and even the Chinese community within a short period of time and enabled him to conduct Buddhist charity activities throughout the whole of Singapore during the Japanese Occupation. The great influence of Lee Choon Seng on the development of Buddhism stemmed from his social network at that time and his pious belief in Buddhism.

First, Lee Choon Seng was a leader in Singaporean Chinese society. Before World War II, he actively resisted Japan, but when Singapore fell into the hands of the Japanese, the Kempeitai did not want to execute him. Instead, the Japanese appointed him to the committee of the Overseas Chinese Association to help the Japanese government collect 5 million dollars from the whole of Malayan (including Singaporean) Chinese society (Chua and Hsu 1984, 
p. 287). Thus, Lee Choon Seng played an important role in the expropriation of money (The Syonan Shimbun 1942, 1943b; Chua and Hsu 1984, p. 356). ${ }^{15}$ Afterward, the association led more than 10,000 Singaporean Chinese refugees to Endau, Johor to develop more than 6000 acres of rural transplantation area (The Syonan Shimbun 1944a). Lee Choon Seng was responsible for managing the local economy and setting up banks for the benefit of the locals (The Syonan Shimbun 1944c; Lee 1950, pp. 23-24, pp. 103-4). In December 1943, Lee Choon Seng was elected vice-chairman of the Overseas Chinese Association and appointed by the Japanese government to the committee of the Syonan Advisory Council who represented the Singaporean Hokkien society (The Syonan Shimbun 1943c). In 1944, Lee Choon Seng, as the vice-chairman of the Overseas Chinese Association, delivered a New Year's message to all Singaporeans in Hokkien on the radio (The Syonan Shimbun 1944b). It can be seen that Lee Choon Seng held a high position in both the Japanese government and Singaporean Chinese society.

Lee Choon Seng took advantage of being the key man of the Japanese, and he made better use of his social influence to conduct Buddhist charity activities. For example, the charity activities of the Chinese Buddhist Relief Association received support from the Japanese government, and the latter even responded actively to provide supplies for refugees (The Syonan Shimbun 1945a, 1945b). When the organization was planning to develop refugee shelters in Batam, it also received high praise from Japanese military officers and they expressed their intention to move refugees there in August 1945 (The Syonan Shimbun 1945b). Besides the Japanese, the Overseas Chinese Association also supported a new film on the theme of the Batam Reclamation and Immigration Conference (The Syonan Shimbun 1945c). It can be seen that without the support of the relevant authorities and social organizations, the various activities advocated for by the Buddhist monks and laymen would not be possible. More importantly, Lee Choon Seng appeared to serve the Japanese, but, in fact, he used Buddhist activities and the Overseas Chinese Association as a cover to protect the young and Buddhists who were spared the suffering of conscription and save their lives (Lee 1950, p. 104). ${ }^{16}$ Xinjiapo huaqiao zhi (新加坡华 侨志) (Tang 1960, p. 198) mentioned Lee Choon Seng's "superficial goodwill". It was concluded that the Chinese Buddhist Relief Association on the surface was cooperating with the Japanese government to cope with the wartime rescue and relief work, but, in fact, it was also a cover to protect school-age youths from being conscripted for military service. So, there were tens of thousands of people who participated in Buddhist charity activities at that time (Tang 1960, p. 198).

As a Buddhist layman, Lee Choon Seng's promotion of the spread of Buddhism in society and the protection of public lives were beyond the reach of monks in Buddhist temples. In the era of the Japanese Occupation, Venerable Puliang, an eminent monk from the Shuanglin Monastery who had previously been actively involved in China's Anti-Japanese War of Resistance, was secretly killed by Japanese Kempetai (Nanyang Siang Pau 1949). ${ }^{17}$ The main reason for the death of Venerable Puliang (普亮) was that the Buddhist monks did not have a strong social network like Lee Choon Seng or other Chinese community leaders. Both their social status and their economic strength were different. Venerable Puliang did not have the chance to serve with the Japanese government, so he was eliminated without hesitation. In comparison, from Lee Choon Seng's presiding over the Shuanglin Monastery to his call to establish the Chinese Buddhist Relief Association, it can be seen that Buddhist laymen had a dominant position in the promotion of Buddhist charity activities, and the monks played a supporting role because the former had a stronger social influence in the community. ${ }^{18}$

Furthermore, Lee Choon Seng was a devout Buddhist. His intention to help the world through Buddhism was the critical factor in the rapid development of Buddhism in Singapore. His writings reveal that he believed that the bodhisattva blessed him when something good happened to him or to others. For example, after he was stranded in Singapore, he said that it was all "thanks to the Buddhas" (承蒙佛恩加被) that he and his family were safe, and after being caught by the Japanese at the base, he saw the "Bodhisattva of Compassion Induction" (菩萨慈悲感应). Thus, he was not shot to death 
(Lee 1950, p. 104). Another example was that he believed that young people and Buddhists survived because of the Chinese Buddhist Relief Association and that their survival should be credited to "my Buddha's mercy" (我佛慈悲) (Lee 1950, p. 104). If Lee Choon Seng was merely talking about Buddhist beliefs and in reality was a greedy and selfish person, then he would not be willing to sacrifice his reputation and become a "lackey" of the Japanese to protect the people, nor set up Chinese Buddhist temples to relieve the masses of their sufferings. In contrast, Lee Choon Seng was still practicing the doctrine of compassion and relief in Mahayana Buddhism during difficult times. He was willing to bear the shame of being branded a "traitor" by the world and used the existing resources of the Buddhist community with his meagre power to help the community (Lee 1950, pp. 52-53). ${ }^{19}$

Lee Choon Seng was once considered a pro-Japanese activist due to his service to the Japanese government. At that time, the Malayan anti-Japanese army shot at him "to eliminate harm to the people" (Chai 2014, p. 34). Fortunately, Lee Choon Seng escaped death by blocking the bullet with an amulet in his chest (Chai 2014, p. 34). In his poems, he expressed his hatred for the atrocities of the Japanese army and his passionate anti-Japanese patriotism, and these indicate that he was stating that he was not genuinely loyal to the Japanese. For example, in "writing a poem to my friends on the way back to Kong Meng San" (出狱回光明山喜晤诸同参), Choon Seng states that “even if I die tens of thousands of times, I can't change my attitude towards the motherland" (Lee 1950, p. 22). In addition, in “Heart of the Lim Bo Seng" (挽林烈士谋盛), he says "to serve the country alone and to die, I deserve to be a man" (Lee 1950, p. 70). These may possibly be understood as showing that his true heart is not pro-Japanese, but stands with the motherland and the people. Except for Lee Choon Seng, the president of the Overseas Chinese Association Lim Boon Keng (林 文庆) seemed humiliated to serve with the Japanese. History records that he tried to commit suicide many times when he was the chairman of the association, but he gave up after being persuaded by others (Lee 1950, p. 104; Chua and Hsu 1984, pp. 293 \& 431-32) ${ }^{20}$ The Overseas Chinese Association not only supported the Chinese Buddhist relief activities that were initiated by Lee Choon Seng, but also, after the surrender of the Japanese, allocated its property to the rehabilitation of the new village, and the remaining funds were transferred to the Singapore Chinese Chamber of Commerce for charity activities (Chua and Hsu 1984, p. 293). At the very least, this shows that the association was still having some positive impact on the Chinese community. Their actions helped to shape a relatively stable environment in the spread of Buddhism in Singapore.

All in all, it could not be denied that the Japanese themselves had a supportive attitude towards Buddhism, but Lee Choon Seng's contribution to Singapore's Buddhism during the Japanese Occupation was undoubtedly immense and should not be ignored. Lee Choon Seng used his social standing, status, and honor to build a shelter for the Singaporean Chinese, and he unswervingly practiced the spirit of "Humanistic Buddhism". Without his support, the Chinese Buddhist temples in Singapore would not have been transformed into large-scale rescue centers that could provide support to people for a long period of time. This was because without the support of powerful social leaders, the Buddhist temples and the Buddhists naturally could not obtain more social and economic resources. Lee Choon Seng was a "spark" of Singapore's Buddhism during this period. He used his influence and credibility in the Chinese community and the support of the Japanese government to promote the rescue activities of Buddhist temples in Singapore. Concurrently, the Buddhist charity activities inexorably attracted believers and strengthened the faith of Buddhist devotees. Although it is impossible to know how much Lee Choon Seng invested in Buddhist philanthropy during the Japanese Occupation, it is undeniable that he made outstanding contributions to Singaporean Buddhism during that time.

\section{Lee Choon Seng's Leadership and the Expansion of Buddhism after World War II}

After World War II, Lee Choon Sheng actively adapted to the economic depression and the huge amount of turbulence in the political climate. He obtained a higher position in the business and political fields. Therefore, he was later elected as the chairman of the 
Singapore Buddhist Federation by the British government. In addition, this was also the reason why he was able to promote the development of Buddhism and relief societies with Buddhist teachings.

Singapore's business activities recovered rapidly after the war. The previous experience of serving the Japanese government did not affect Lee Choon Seng's reputation. The Buddhist charity activities conducted by Lee Choon Seng during the Japanese Occupation had become deeply rooted in the hearts of the people; thus, its influence in Singaporean society rapidly increased. First, Lee Choon Seng was elected as the special director of the Singapore Chinese Chamber of Commerce from 1946 to 1949 and served as the vice-chairman of OCBC Bank (Singapore Chinese Chamber of Commerce \& Industry 1982, pp. 242-44). ${ }^{21}$ After the separation of Malaysia and Singapore, Choon Seng held a general meeting of shareholders of OCBC Bank to emphasize the need for the two countries to maintain a common currency and a unified banking system in order to achieve economic exchanges and prosperity (Nanyang Siang Pau 1966a). Additionally, from the fact that Choon Seng's daughter Wai Chan had married into a wealthy family in 1954 (The Straits Times 1954; The Singapore Free Press and Mercantile Advertiser 1938), ${ }^{22}$ it is not difficult to think that Lee Chon Seng had planned to maintain his and his family's position in the business field. Although after the period of Japanese Occupation Lee Choon Seng felt that he was already in his advanced years and even deliberately wanted to live out his last surviving years quietly (Lee 1950, p. 104), his social influence continued to expand. The success of Lee Choon Seng in his business career after the war became a key factor in his being selected by the British government to become a Singaporean Buddhist leader.

After the Japanese Occupation, the percentage of Buddhists in Singapore grew rapidly. Furthermore, with Singapore on the verge of independence and self-government, the establishment of the People's Republic of China in 1949 caused an interruption in the Buddhist belief network between the two places and the arrival of a large number of eminent monks from the south, which further complicated the Buddhist situation in Singapore. To have a better dialogue with Buddhist organizations, the British government commissioned Lee Choon Seng to form a Buddhist Federation to unify the various Buddhist religious groups in Singapore. In 1949, the Singapore Buddhist Federation was formally established by Lee Choon Seng in collaboration with other Buddhist monks and laymen such as Venerable Hong Choon (宏船), Venerable Zhuan'an (转岸), Venerable Daming (达 明), and Chng Pee Tong (庄丕唐). Lee Choon Seng was re-elected as chairman for seven terms until 1964 (The Straits Times 1949; Nanyang Siang Pau 1963, 1966b; The Straits Times 1966; Chia 2008; Chia 2016, pp. 146-47; Hue 2013, p. 190). ${ }^{23}$ The establishment of the association was an important indicator of the development of Buddhism in Singapore. It also showed that the highest Buddhist institution in Singapore was led by a Buddhist layman. This not only subverted the traditional practice of monks as leaders and laymen as subordinates in the Buddhist world but also injected different new elements into the development of Singaporean Buddhism.

The British government's recommendation of Choon Seng as the chairman of the Buddhist Federation was based on practical reasons. Firstly, Lee Choon Seng had good interactions with the local colonial government. In 1940, he donated 32,000 dollars, raised by the Singapore China Relief Fund, to the British government as war expenses (The Straits Times 1941). As a result, he was awarded a medal by the Governor of the Straits Settlements, Thomas, and was praised for his great contributions to China and the United Kingdom (Nanyang Siang Pau 1941; Lee 1950, p. 1). After World War II, Lee Choon Seng began shifting his Chinese identity to a local identity. He gained Singapore's British citizenship in 1952 (The Straits Times 1952) and, in the same year, led the members of Buddhist Federations to pray for the death of the king of the United Kingdom (The Singapore Free Press 1952). Hence, Lee Choon Seng maintained a good relationship with the British government and had won the trust of the British. Additionally, Lee Choon Seng himself had already established a certain reputation and status in the local Buddhist 
community and society during the Japanese Occupation. Therefore, his appointment gained the acceptance of the Buddhist monks and the public. It also proved once again that the development of Buddhism in Singapore must be integrated with society. After Lee Choon Seng assumed the chairmanship of the Singapore Buddhist Federation, he focused on the development of Mahayana Buddhism, that is, the implementation of Buddhist education in Humanistic Buddhism to benefit the world and to promote self-reliance (Lee 1950, pp. 115-17). ${ }^{24}$

In the first three years after the establishment of the Singapore Buddhist Federation, Lee Choon Seng successively funded the establishment of the Singapore Maha Bodhi School and several Buddhist public cemeteries. In 1951, Lee Choon Seng accepted the invitation of Miss Pitt Chin Hui (毕俊辉) to serve as the chairman of the board of directors of the Maha Bodhi School (Maha Bodhi School 2021) and personally organized the school fundraising committee to raise funds for the purchase of the Geylang Lane 34 site as the school's base. ${ }^{25}$ The number of students at the school reached more than one thousand in the 1960s (Singapore Standard 1951; The Straits Times 1950; Maha Bodhi School 2021). The establishment of the Maha Bodhi School was an important part of the practice of Buddhist education between Lee Choon Seng and the Singapore Buddhist Federation. The Buddhist school's mission was to promote the teachings of Buddhism, ensuring that new generations of Singaporeans could stay connected to and understand the Dharma. Moreover, in 1952, Lee Choon Seng sought the consent of his father-in-law, Mr. Chen Huan Qi (陈焕其), to donate about 100 acres in Choa Chu Kang to the Singapore Buddhist Federation for Singapore's first Buddhist public cemetery. In 1959, Lee Choon Seng officially implemented the Buddhist public cemetery (Chia 2016, p. 147; Sin Chew Daily 1959). The Chinese have always attached significant importance to life and death. The hosting of the Maha Bodhi Chinese School and the Buddhist public cemetery showed that Lee Choon Seng was trying to help traditional Chinese culture continue its development in this foreign country. After his decades of promotion, it also symbolized the fact that Chinese Buddhism had officially become mature in Singapore.

Another major characteristic of Lee Choon Seng's Buddhist thought was that Chinese Buddhism had gradually become localized under his leadership and had finally merged with the other Buddhist religious groups to form a local and united Singaporean Buddhism. Before 1949, the Singapore Buddhist Lodge and the Chinese Buddhist Relief Association, which were both founded by Lee Choon Seng, had strong Chinese characteristics and were only active in Chinese communities and Chinese Buddhist temples. ${ }^{26}$ However, after the period of Japanese Occupation, China experienced civil war and the founding of the People's Republic of China, Buddhism declined in the local area, and the South China Sea Buddhist networks that had formed in the early stage were interrupted, which led to the weakening of Chinese Buddhism in Singapore's national identity. It gradually moved towards the localization of local society (Chia 2020a, p. 14; Hue 2013, pp. 133-34). The establishment of the Singapore Buddhist Federation emphasized the geographical location of "Singapore". During this time, the Buddhist association led by Choon Seng not only represented the Chinese, but also the whole community of Singapore. After Lee Choon Seng switched from a Chinese to a local identity, he also began to promote activities that crossed ethnic boundaries and sought the welfare of all Buddhists and even the whole of society. For example, in 1950, Lee Choon Seng publicly called on the Straits Settlements government to approve Vesak Day as a public holiday (Malaya Tribune 1950). The religious representatives who participated in this appeal were not from Chinese Buddhist organizations, but from other local Buddhist organizations such as Siam and Sri Lanka (Malaya Tribune 1950; The Singapore Free Press 1955). The British government finally approved the Buddhist Vesak Day (April 15th of the lunar calendar) as a statutory public holiday in Singapore in 1955 (Chia 2016, p. 147; The Singapore Free Press 1955). It did not just represent the fact that the Singaporean government officially recognized the status of Buddhism, but could also be considered a victory achieved by Buddhists of all ethnic groups who were united in their struggle, which displayed the diversity and co-prosperity of Buddhism in Singapore. 
Additionally, Lee Choon Seng spent 70,000 dollars to build the Poh Ern Shih Temple on the hillside near Pasir Panjang in 1954 (The Straits Times 1953; Poh Ern Shih 2021). The temple is one of the few Mahayana Buddhist temples in Singapore that worships the Ksitigarbha Bodhisattva (Poh Ern Shih 2021). At the time, English newspapers reported that the Buddhist temple was built for the Chinese community since it was constructed in a traditional Chinese architectural style (The Straits Times 1953). However, in fact, Choon Seng's original intention was to build the temple to commemorate the 1400 Malay soldiers who died in the Pasir Panjang battle during the Japanese Occupation (Poh Ern Shih 2021). Therefore, the temple enshrined the Ksitigarbha Bodhisattva to save the deceased soldiers' "souls" and "free [them] from the sea of suffering". Lee Choon Seng commemorated the Malaysian soldiers, the majority of whom were Muslim, with a Buddhist temple, which reflects his religious tolerance and diversity that has made Singapore's Buddhism accord with the multicultural society. Today, Poh Ern Shih is continuing Choon Seng's spirit, that is, retaining the practice and traditions of Mahayana Buddhism, conducting religious charity activities, and providing venues for Hinayana Buddhist associations to enhance the relationships between each other (Poh Ern Shih 2021).

While advancing Buddhism towards the pathway of cross-ethnicity and diversity, the Singapore Buddhist Federation led by Lee Choon Seng also made close contact with the local Chinese community. In 1961, the association helped Tan Kah Kee Scholarships to raise funds and made donations that totaled more than 10,000 dollars (Sin Chew Daily 1961). Among them, the chairman Lee Choon Seng donated 2000 dollars (Sin Chew Daily 1961). In April 1963, the Buddhist Federation issued an official letter to invite Buddhist groups to participate in activities organized by the Chinese Chamber of Commerce, such as the setting up of a monument for people in distress during the period of Japanese Occupation (Sin Chew Daily 1963). From the above, it can be seen that Choon Seng was a leader of Singaporean Buddhism who still maintained his social network and participated in the public welfare activities of the Chinese community. In other words, Lee Choon Seng was able to strike a balance between the "in" and the "out", between society and religion, by using his social relationship and resources that were "in" society to promote Buddhism to the community. Lee Choon Seng brought the theory and spirit of "Humanistic Buddhism" into full play. Therefore, the good reputation of Choon Seng in the political, business, and Buddhist circles explains why this Buddhist layman was able to serve as the highest Buddhist leader in Singapore for close to 15 years.

In summary, it was practical and necessary for Lee Choon Seng to assume the chairmanship of the Buddhist Federation given the economic and political background in Singapore. During this time, Choon Seng cooperated with a group of Buddhist monks and laymen to weave the Buddhist network in Singapore by proposing a combination of "Mahayana Buddhist teachings" and "social charity welfare" to spread the idea of Buddhist philanthropy. Additionally, Chinese Buddhism started to cross over from the Chinese community to the whole public without ethnic boundaries, which expanded the influence of Buddhism in Singapore. The change in the development of Singaporean Buddhism in that period also strengthened the recognition of the religion by the local community and promoted the rapid spread of Buddhism after its localization. The establishment of the Singapore Buddhist Federation and the approval of Vesak Day as a public holiday were signs of the integration of Chinese Buddhism into society, which became a part of Singapore's Buddhism and multicultural society. Like other prominent Chinese migrant monks of the time, Lee Choon Seng led the development of "institutional" Chinese Buddhism, supporting the propagation of Buddhist teachings to the overseas Chinese community (Chia 2020b, pp. 24-30).

\section{Conclusions}

As an important businessman in Singaporean society, Lee Choon Seng connected with Buddhism in his early years due to his family and personal relationships. Thereafter, Choon Seng was influenced by modern Chinese Buddhist teachings that emphasized 
caring for society, one's country, and the world. He did not forget to utilize the Buddhist spirit to engage in charity and national salvation activities. When he had become wealthy and a leader in the local Chinese community, he ensured that Chinese Buddhism would successfully establish a foothold in the Chinese community in Singapore. Due to the particular features of the period, Lee Choon Seng transformed from a Buddhist patron into the most prominent lay Buddhist leader in Singapore. During the Japanese Occupation, while backed by his social status and influence, he called on Chinese Buddhists throughout the entire country to initiate Buddhist charity works to help refugees and the poor. At that time, the rapid growth in the number of Buddhists converged into a huge developmental trend since many people benefited from Buddhism. After World War II, Choon Seng maintained his social influence in the community, and his appeal in the Buddhist world far surpassed that of the Buddhist monks. Hence, it was a time for him, as a Buddhist layman, to lead the Buddhists.

The importance of Lee Choon Seng to Buddhism lies in his lifelong association with Buddhism and the different influences he brought to the development of Buddhism in Singapore at each stage. The Buddhism practiced by the early Chinese followers in Singapore was mixed with elements of folk beliefs and could not be considered pure Buddhism. It was only after Chinese Buddhism underwent a revival movement that the concept of humanistic Buddhism, as advocated by Master Tai $\mathrm{Xu}$, spread to Singapore through the South China Sea Buddhist network. Then, modern Chinese Buddhism was promoted by Lee Choon Seng and other monks and laymen, especially through the establishment of the Singapore Buddhist Lodge and the theory of Buddhist salvation put forward by it, laying a solid foundation for the rapid spread of Chinese Mahayana Buddhism in the local community. During the period of Japanese rule, refugees and the war led Lee Choon Seng to advocate for a combination of Mahayana Buddhism and social charity and welfare, which led to the rapid development of Mahayana Buddhist philanthropy. Although the Buddhist network between Singapore and China was disrupted after World War II, the growth and popularity of Buddhist philanthropy during the period of Japanese rule did not stop the religion from becoming intellectualized and organized into a model of Humanistic Buddhism. Today, Buddhism in Singapore has become a fully localized religion, and its active self-interest in benefitting others through social charity, education, and culture, which is equivalent to the concept of Master Taixu's Humanistic Buddhism, continues to be practiced in the Buddhist community. Lee Choon Seng has been instrumental in promoting this Buddhist spirit.

Author Contributions: Conceptualization, G.T.H. and J.K.K.C.; Data curation, G.T.H., C.T. and J.K.K.C.; Formal analysis, G.T.H. and J.K.K.C.; Funding acquisition, G.T.H.; Investigation, G.T.H., C.T. and J.K.K.C.; Methodology, G.T.H. and J.K.K.C.; Project administration, G.T.H., C.T. and J.K.K.C.; Resources, G.T.H., C.T. and J.K.K.C.; Supervision, G.T.H. and J.K.K.C.; Validation, G.T.H.; Visualization, G.T.H.; Writing—original draft, G.T.H., C.T. and J.K.K.C.; Writing—review \& editing, G.T.H., C.T. and J.K.K.C. All authors have read and agreed to the published version of the manuscript.

Funding: This research received no external funding.

Informed Consent Statement: Not applicable.

Conflicts of Interest: The authors declare no conflict of interest.

\section{Notes}

1 Lee Lip Chai ran a grocery store business in Seremban. After Lee Choon Seng came to Nanyang, he followed his father by doing business, then founded a grocery store branch, Thye Hin Limited, in Singapore at the age of 26. Later, he bought the Thye Hong Biscuit Factory and founded Thye Ann Investment, a property firm. He presided over the merger of Ho Hong Bank, Overseas Chinese Bank, and Wah Seng Bank into the Overseas Chinese Banking Corporation (OCBC). After that, Choon Seng became known as a Singaporean banker and was active in the local banking business sector until his death.

2 Master Taixu from China was invited to Singapore to promote Buddhism in 1926. It was believed that this was an important opportunity to boost up the future development of Buddhism in Singapore and Malaysia (see Chia 2020b, pp. 36-40).

3 Master Yinguang did not use the money sent by Choon Seng. He used the first 2000 dollars to do Buddhist rituals for Choon Seng's parents; the other 3000 dollars were used to print Buddhist scriptures. 
4 The pure land revival movement was held through the process of the meetings and written correspondence by Master Yinguang with lay followers. Master Yinguang cultivated a lot of new elite lay followers among the major cities in the lower Yangzi region, including businessmen, officials, and activists.

5 Shanghai Lay Buddhist Grove was formed in 1920. Later, it was split and reorganized into the Shanghai Buddhist Pure Karma Society and the World Lay Buddhist Grove.

6 Ho Hong Bank, Overseas Chinese Bank, and Wah Seng Bank were merged into the Overseas Chinese Banking Corporation (OCBC) in 1933, and Lee Choon Seng served as a committee member of the director board for a long time.

At that time, Tan Kah Kee left Singapore for half a year, so his assistant Lee Choon Seng assumed the position as acting chairman.

Lee Choon Seng had been pursuing this balance throughout his life. He actively developed the company, expanded the business materially, and accumulated a wealth of material possessions. At the same time, he also used Buddhism, literature, aesthetics, etc. to relax his heart.

9 According to the field studies and investigations of British scholar Colin Mc Dougall after the war, it was found that, during the Japanese Occupation in the major cities of Malaya, the Japanese army had a very friendly attitude towards Buddhist monks and laymen. At that time, the temples and nunneries were also allowed to continue their religious activities, and some Buddhist groups even received financial support from the Japanese government to encourage them to continue their charity work. In fact, when Japanese troops were stationed near the Kwan Im Thong Hood Cho Temple on Waterloo Street (the Chinese Buddhist Relief Association also took in refugees in this temple), the Japanese military officers walked into the hall to inspect, and "not only did they not search them, but they even distributed cigarettes to the refugees for their leisure.".

According to the records by Venerable Beng Tee (明智), the number of Buddhist followers increased to more than 100,000 during the Japanese Occupation period.

Lee Choon Seng originally planned to flee to India, but because his passport procedures were delayed and the flight route was cut off, he was not able to escape from Singapore.

A number of meeting records and document files of the Syonan Overseas Chinese Association include the name of Lee Choon Seng, proving that he was one of the members of the organization. In addition, the "Syonan Shimbun" published by the Japanese government also contained Lee Choon Seng's deeds in assuming a role in the Overseas Chinese Association.

The Japanese government always supported Buddhist activities, such as providing rice, salt, food, and clothing to the Chinese Buddhist Relief Association to help the refugees.

At that moment, there were two large relief teams in Singapore. One of them was the Chinese Buddhist Relief Association, which was responsible for the relief of the living; the other was the non-Buddhist charity organization Blue Cross Charitable Institution, which dealt with the dead and took the injured to the hospital.

Lee Choon Seng was responsible for the payment of the money, and explained that the five Chinese banks in Singapore had prepared 1,200,000 dollars to provide loans to the Chinese community to help them pay the money. In addition, when the Overseas Chinese Association handed over a check for fifty million dollars to the Japanese government, Lee Choon Seng was one of the five leaders who signed the cheque. After paying the entitlement money, the Japanese government also awarded Lee Choon Seng and other Chinese leaders a medal for their "contributions" to the society.

Lee Choon Seng mentioned in his writings that "more than two thousand Buddhists and young people and more than 10,000 people in the Chinese villages of Endau, who were protected by the Buddha's mercy, were exempted from conscription and replenishment." In fact, he trusted the Overseas Chinese Association and, with the blessing of the Chinese Buddhist Relief Association, again played a key role in it.

Venerable Puliang was arrested by the Japanese army and there was no more news about him. It is generally believed that he was killed.

It also paved the way for the British government to choose Lee Choon Seng, a Buddhist layman instead of a monk, to serve as the chairman of the Singapore Buddhist Federation after World War II.

As his poem states, "After three and a half years of occupation, who knows how to die, save today's affairs for future generations to see. To bear the humiliation and repay the world, with sorrow in the lungs and liver, the storm is exhausted, and he feels peace of mind." This shows that he was willing to bear these humiliations, and that it is up to posterity to evaluate his behavior.

After the end of World War II, Lee Choon Seng also pointed out that his body, mind, and soul had been severely damaged. He did not want to see the occurrence of World War III. He only wanted to go to the Western Paradise as soon as possible to reflect on his suffering and pain over the past three years. Leaders of other overseas Chinese associations, such as Lim Boon Keng, were also humiliated. He had tried to commit suicide many times when he was the chairman of the Overseas Chinese Association, but he gave up after being persuaded by others. The “Xinma huaren kangri shiliao 新马华人抗日史料”, edited by Hsu Yun Tsiao, also affirms the contribution of the leaders of the Overseas Chinese Association to the Chinese community. He understood that most Chinese leaders who cooperated with the Japanese government took their hardship as a last resort, and were not truly loyal to the Japanese.

After 1960, Lee Choon Seng was nominated to be the honorable president of the Singapore Chinese Chamber of Commerce until his death. 
Wai Chan's husband Tan Koen Tjoan was the nephew of Tan Hoan Kie, chairman of the Aurora company. Lee Choon Seng's second daughter, Lee Yeow Tin, was also married into a wealthy family in 1938. Yeow Tin 's husband, Lim Kok Boon, was the fourth son of Lim Kim Tian, the chairman of the Chinese Twakow Owner Guild. It can be seen that marrying into a local wealthy family was important to Lee Choon Seng's family in order to expand its business network. Venerable Hong Choon served as the vice-chairman and became the chairman after Lee Choon Seng stepped down in 1964.

After the establishment of the Singapore Buddhist Federation, the promotion of Buddhism education and the establishment of charities were the two major missions the organization wanted to pursue. The other three missions were to support world peace, promote Buddhist truths, and reform the Buddhist system.

The Singapore Maha Bodhi School was founded in 1946. It was the first secular Buddhist school in Singapore. It was also a Chinese school that took Chinese as a medium. At the beginning of its establishment, there were only 40 students.

Of course, during the Japanese Occupation period, the Chinese Buddhist Relief Association also began to help refugees regardless of ethnicity. This could be regarded as a transitional stage for Chinese Buddhism as it began to cross ethnic boundaries.

\section{References}

Abeyratne, H. G. 1956. Buddha Jayanti Souvenir: To Commemorate the 2500th Anniversary. Singapore: The Singapore Regional Centre of The World Fellowship of Buddhists.

Bingenheimer, Marcus. 2007. Some Remarks on the Usage of Renjian Fojiao and the Contribution of Venerable Yinshun to Chinese BuddhistModernism. In Development and Practice of Humanitarian Buddhism: Interdisciplinary Perspectives. Edited by Mutsu Hsu, Jinhua Chen and Lori Meeks. Hualien: Tzu Chi University Press, pp. 141-61.

Chai, You Xia 蔡佑霞. 2014. Lee Choon Seng: 20 Shiji Zhongye de Xinjiapo Huashe Lingxiu 李俊承: 20世纪中叶的新加坡华社领袖 [Lee Choon Seng: Chinese Community Leader in Singapore in The Mid-20th Century]. Bachelor thesis, National University of Singapore, Singapore.

Chia, Jack Meng-Tat. 2008. Buddhism in Singapore-China Relations: Venerable Hong Choon and his Visits, 1982-1990. The China Quarterly 196: 864-83. [CrossRef]

Chia, Jack Meng-Tat. 2016. Defending the Dharma: Buddhist Activism in a Global City-State. In Singapore: Negotiating State and Society, 1965-2015. Edited by Jason Lim and Terence Lee. New York: Routledge, pp. 143-58.

Chia, Jack Meng-Tat. 2020a. Diaspora's Dharma: Buddhist Connections across the South China Sea, 1900-1949. Contemporary Buddhism, 1-18. [CrossRef]

Chia, Jack Meng-Tat. 2020b. Monks in Motion: Buddhism and Modernity across the South China Sea. New York: Oxford University Press.

Chua, Ser Koon 蔡史君, and Yun Tsiao Hsu 许云樵. 1984. Xinma Huaren Kangri Shiliao 新马华人抗日史料 1937-1945 [Malayan Chinese Resistance to Japan 1937-1945]. Singapore: Wenshi Chuban Gongsi.

Ho, Yi Kai 何奕恺. 2013. Jueyuan shi chu tan 觉园诗初探 [Initial analysis on jueyuan poetry]. Wenxue 文学 3: 28-34.

Hue, Guan Thye 许源泰. 2013. Yan'ge Yu Moshi: Xinjiapo Daojiao he Fojiao de Chuanbo Yanjiu 沿革与模式: 新加坡道教和佛教传播研究 [Evolution and Patterns: A Study of Taoism and The Dissemination of Buddhism in Singapore]. Monograph Series on Southeast Asian Chinese; Singapore: National University of Singapore Department of Chinese Studies and Global Publishing, vol. 12.

Jan, Kiely. 2016. Master Yinguang and His Pure Land Revival Movement. In Making Saints in Modern China. Edited by David Ownby, Vincent Goossaert and Zhe Ji. New York: Oxford University Press, pp. 30-77.

Jessica, L. Main, and Rongdao Lai. 2013. Reformulating “Socially Engaged Buddhism" as an Analytical Category. The Eastern Buddhist 44: $1-34$

Jia, Zhang, and Ji Zhe. 2018. Lay Buddhism in Contemporary China: Social Engagements and Political Regulations. China Review 18: $11-40$.

Kimball, Richard L. 2000. Humanistic Buddhism as Conceived and Interpreted by Grand Master Hsing Yun of Fo Guang Shan. Hsi Lai Journal of Humanistic Buddhism 1: 1-52.

Kua, Bak Lim 柯木林. 2012. Shijie Fujian Mingren Lu: Xinjiapo Pian 世界福建名人录: 新加坡篇 [Who's Who in Fujian in the World: Singapore]. Singapore: Xinjiapo Fujian huiguan.

Laliberté, André, David A. Palmer, and Keping Wu. 2011. Religious Philanthropy and Chinese Civil Society. In Chinese Religious Life. Edited by David A. Palmer, Glenn Shive and Philip L. Wickeri. Oxford: Oxford University Press, pp. 139-51.

Lee, Choon Seng 李俊承. 1940. Yindu Gufoguo Youji 印度古佛国游记 [A Journey to the Ancient Buddhist Kingdom of India]. Singapore: Xinjiapo Fojiao Jushilin.

Lee, Choon Seng 李俊承. 1950. Jueyuan Ji 觉圆集 [Jueyuan Poetry Anthology]. Singapore: Nanyang Printing Co. Ltd.

Lee, Choon Seng 李俊承. 1956. Jueyuan Xuji 觉圆续集 [Jueyuan Sequel]. Singapore: Nanyang Printing Co. Ltd.

Long, Darui Long. 2000. Humanistic Buddhism from Venerable Tai Xu to Grand Master Hsing Yun. Hsi Lai Journal of Humanistic Buddhism 1: 53-84.

Maha Bodhi School. 2021. History. Available online: https://www.mahabodhi.moe.edu.sg/about-mbs/history/ (accessed on 5 December 2021).

Malaya Tribune. 1931. Local Chinese Meeting for Relief Fund. Malaya Tribune, August 17, p. 8.

Malaya Tribune. 1933. Advertisements Column 3. Malaya Tribune, April 5, p. 6.

Malaya Tribune. 1938. Advertisements Column 3. Malaya Tribune, December 2, p. 6. 
Malaya Tribune. 1950. Appeal To Make Vesak Day Holiday. Malaya Tribune, May 2, p. 8.

Morning Tribune. 1936. Advertisements Column 1. Malaya Tribune, February 17, p. 4.

Nanyang Siang Pau. 1933. Advertisements Column. Nanyang Siang Pau, August 15, p. 2.

Nanyang Siang Pau. 1937. Untitled. Nanyang Siang Pau, December 4, p. 7.

Nanyang Siang Pau. 1939. Untitled. Nanyang Siang Pau, May 3, p. 6.

Nanyang Siang Pau. 1940. Untitled. Nanyang Siang Pau, March 11, p. 6.

Nanyang Siang Pau. 1941. Untitled. Nanyang Siang Pau, August 25, p. 21.

Nanyang Siang Pau. 1949. Untitled. Nanyang Siang Pau, December 12, p. 5.

Nanyang Siang Pau. 1963. Untitled. Nanyang Siang Pau, July 20, p. 13.

Nanyang Siang Pau. 1966a. Untitled. Nanyang Siang Pau, May 15, p. 20.

Nanyang Siang Pau. 1966b. Untitled. Nanyang Siang Pau, June 10, p. 14.

Poh Ern Shih. 2021. Our History. Available online: https:/ / pohernshih.org.sg/who-we-are/ (accessed on 2 December 2021).

Ritzinger, Justin R. 2017. Parsing Buddhist Modernity in Republican China. Ten Contrasting Terms. In Buddhist Modernities: Re-Inventing Tradition in the Globalizing Modern World. Edited by Hanna Havnevik, Ute Hüsken, Mark Teeuwen, Vladimir Tikhonov and Koen Wellens. London and New York: Routledge, pp. 51-65.

Sheng, Kai 圣凯. 2019. Xinjiapo hanchuan fojiao de xiandaihua shijian 新加坡汉传佛教的现代化实践 [The modernization of Chinese Buddhism in Singapore]. The World Religious Cultures 3: 45-53.

Shi, Yinguang 释印光. 2021a. Zengguang Yinguangfashi Wenchao: Yongchun Chongxiu Dongguanqiao Linggan Ji 增广印光法师文钞: 永春重修东关桥观音灵感记. Available online: http://www.donglin.org/wk/zhushu/zhu_13/1.\%E5\%A2\%9E\%E5\%B9\%BF\%E6 \%96\%87\%E9\%92\%9E/\%E5\%8D\%B7\%E5\%9B\%9B/1.\%E8\%AE\%B0/38.\%E6\%B0\%B8\%E6\%98\%A5\%E9\%87\%8D \%E4\%BF\%AE\% E4\%B8\%9C\%E5\%85\%B3\%E6\%A1\%A5\%E8\%A7\%82\%E9\%9F\%B3\%E7\%81\%B5\%E6\%84\%9F\%E8\%AE \%B0.htm \T1 $\backslash$ textgreater\{\} (accessed on 1 December 2021).

Shi, Yinguang 释印光. 2021b. Yinguang Fashi Wenchao Sanbian: Fu Yitong Fashi Shu Er 印光法师文钞三编: 复义通法师书二. Available online: http:/ / www.donglin.org/wk/zhushu/zhu_13/3.\%E6\%96\%87\%E9\%92\%9E\%E4\%B8\%89\%E7\%BC\%96/\%E5\%8D\%B7 \%E4\%B8\%80/016.\%E5\%A4\%8D\%E4\%B9\%89\%E9\%80\%9A\%E6\%B3\%95\%E5\%B8\%88\%E4\%B9\%A6\%E4\%BA \%8C.htm (accessed on 1 December 2021).

Sin Chew Daily. 1959. Untitled. Sin Chew Daily, March 16, p. 6.

Sin Chew Daily. 1961. Untitled. Sin Chew Daily, October 7, p. 8.

Sin Chew Daily. 1963. Untitled. Sin Chew Daily, April 16, p. 5.

Singapore Chinese Chamber of Commerce \& Industry. 1982. Xinjiapo Zhonghua Zongshanghui Qishiwu Zhounian Jinian(1906-1981) 新 加坡中华总商会七十五周年纪念 (1906-1981) [Singapore Chinese General Chamber of Commerce E Industry 75th Anniversary Special Issue, 1906-1981]. Singapore: Xinjiapo Zhonghua Zongshang Hui.

Singapore Standard. 1951. New School Founded. Singapore Standard, January 22, p. 2.

Tan, Chew Peng 陈秋平. 2009. Renjian Fojiao Zai Malaiya de Chuanbo Yu Fazhan人间佛教在马来亚的传播与发展 [The Spread and Development of Humanistic Buddhism in Malaya]. Studies in World Religions 3: 31-37.

Tang, Zhiyao 唐志尧. 1960. Xinjiapo Huaqiao Zhi 新加坡华侨志 [Overseas Chinese Chronicles In Singapore]. Taiwan: Chinese Overseas Publishing House.

The Singapore Buddhist Lodge 新加坡佛教居士林. 2021. Organizational Profile. Available online: http://www.sbl.org.sg/chn/aboutus.aspx (accessed on 4 December 2021).

The Singapore Free Press and Mercantile Advertiser. 1938. The Singapore Free Press and Mercantile Advertiser, January 14.

The Singapore Free Press. 1952. Prayers for the King. The Singapore Free Press, February 13, p. 5.

The Singapore Free Press. 1955. Untitled. The Singapore Free Press, June 18, p. 2.

The Straits Times. 1940. Mr. Tan Kah Kee Leaves To-day. The Straits Times, March 14, p. 10.

The Straits Times. 1941. \$32,000 for Raid Relief. The Straits Times, January 3, p. 11.

The Straits Times. 1949. New Federation of Buddhists Formed. The Straits Times, August 3, p. 5.

The Straits Times. 1950. Teacher Back From Talks. The Straits Times, July 19, p. 4.

The Straits Times. 1952. 51 more become British subjects. The Straits Times, July 5, p. 8.

The Straits Times. 1953. Mr. Lee's Dream Temple Comes True. The Straits Times, August 4, p. 5.

The Straits Times. 1954. 1000 Guests for Wedding. The Straits Times, March 25, p. 8.

The Straits Times. 1966. Leading S'ore banker Lee dies at 82. The Straits Times, June 6, p. 5.

The Syonan Shimbun. 1942. Five Chinese Banks Allow Overdrafts. The Syonan Shimbun, May 8, p. 5.

The Syonan Shimbun. 1943a. Historic Buddhist Temple Now Houses Home For The Aged. The Syonan Shimbun, January 30 , p. 2.

The Syonan Shimbun. 1943b. Given Certificates of Honour. The Syonan Shimbun, December 9, p. 1.

The Syonan Shimbun. 1943c. Sanji Kai Introduces Two Innovations. The Syonan Shimbun, December 10, p. 2.

The Syonan Shimbun. 1944a. Finance Agency Established At New Syonan. The Syonan Shimbun, January 17, p. 1.

The Syonan Shimbun. 1944b. Miscellaneous Column 2. The Syonan Shimbun, January 25, p. 2.

The Syonan Shimbun. 1944c. Gunsei Gift Earns Chinese Gratitude. The Syonan Shimbun, February 11, p. 1.

The Syonan Shimbun. 1945a. Buddhists Actively Engaged In Extensive Relief Work In Syonan. The Syonan Shimbun, March 7, p. 2.

The Syonan Shimbun. 1945b. Untitled. The Syonan Shimbun, July 20, p. 2. 
The Syonan Shimbun. 1945c. O.C.A. Lecture Meeting. The Syonan Shimbun, August 7, p. 2.

Wei, Tao. 2007. Pure Mind, Pure Land A Brief Study of Modern Chinese Pure Land Thought and Movement. Master's thesis, McGill University, Montreal, QC, Canada.

Zhang, Wenxue 张文学. 2014. Zhuandao heshang chuangli xinjiapo Putuosi, Pujuechansi xiangguan wenti yanjiu 转道和尚创建新加坡 普陀寺、普觉禅寺相关问题研究 [A study on the problems related to the establishment of Putuo Temple and Pujue Temple in Singapore by Zhuandao]. The World Religious Cultures 5: 23-27. 